\title{
THE PERCEPTION OF RESPONDENTS OF INTELLIGENT PACKAGING IN SLOVAKIA AS ECOLOGICAL INNOVATIONS
}

\section{Erika Loučanová*, PhD.}

Technical University in Zvolen, The Faculty of Wood Sciences and Technologies, Department of Marketing, Trade and World Forestry, Slovak Republic

E-mail: loucanova@tuzvo.sk

Ján Parobek, PhD.

Technical University in Zvolen, The Faculty of Wood Sciences and Technologies, Department of Marketing, Trade and World Forestry, Slovak Republic

E-mail:parobek@tuzvo.sk

\section{Martina Nosál'ová, PhD.}

Technical University in Zvolen, The Faculty of Wood Sciences and Technologies, Department of Marketing, Trade and World Forestry, Slovak Republic

E-mail: nosalova@tuzvo.sk

\author{
prof. Ana Dopico \\ University of Vigo, \\ 36005 Pontevedra, Spain \\ E-mail: adopico@uvigo.es
}

(Received: December 2018; Accepted: February 2019; Published: March 2019)

\begin{abstract}
The research of new active and intelligent features has shown huge potential to optimise the supply chain and enhance consumer consciousness of food utilisation. The paper deals with the evaluation of the perception of intelligent packaging in Slovakia as ecological innovations through the Kano model. It focuses on to analysis the perception of different intelligent packaging features. The results indicate that customers' awareness of intelligent packaging is still at a very low level in Slovakia.
\end{abstract}

Keywords: innovation, intelligent packaging, ecological innovations.

JEL Codes: O31, O32

* Corresponding author: Erika Loučanová.E-mail: loucanova@tuzvo.sk 
Loučanová, E., Parobek, J., Nosál’ová, M., Dopico, A. (2019)

The perception of respondents of intelligent packaging in Slovakia as ecological innovations

\section{Introduction}

Companies should monitor changes in consumers' perception when choosing their marketing. On the other side, companies must also focus on competition and on the new packaging technologies. Today, packaging is a marketing tool where companies reveal the relationship to the environment and nature. For example, companies can determine whether use limited or recycled materials (PajtinkováBartáková, Gubíniová, 2012; Šupín, 2009, Paluš, 2004, Loučanová et al., 2016). Therefore, on the one hand it is important to create a good quality packaging but on the other hand company has a responsibility how it could be re-used (e.g. recycling) According to the main idea of the research we tried to analyze the perception of respondents of intelligent packaging in Slovakia.

\section{Literature review}

The packaging can be understood as a tool or set of tools to protect the products from a potential damage. It allows better handling, facilitates the marketing and consumption of products (Zeman, 2005).

Two types of packaging materials are identified with a high and low-degree of proactive behavior. The auxiliary packaging material is a part of the package which ensures full functionality of packaging and fulfills specific packaging tasks. For example, auxiliary packaging material involves nails, adhesives, labels, corks or caps (Dzurová, 1997; Kačenák 1996; Zeman, 2005; Loučanová et al., 2016; Straka, 2013).

The approach to packaging materials and techniques has been changed as a result of global changes during recent decades. At the present time the packaging has a great potential to contribute to sustainable development. However, it is necessary to ensure know-how on how packaging features and properties affect sustainable development among producers, consumers and suppliers (Loučanová, et al., 2016). Today the packagings have a lot of intelligent solutions and innovation.

Intelligent packaging is associated with the performance of smart functions with to goal as monitoring to extend shelf life, warning about potential problems, ensuring product safety, quality and product information (Yam et al., 2005).

The intelligent innovations are "any autonomic changes with positive impact to the customers". They are healthier, safer, increase the comfort of the customer and concurrently they represent a more efficient (Loučanová, 2017).

In the other words the intelligent packaging is aligned with intelligent innovation. The intelligent innovations, as well as intelligent packaging, are closely related to sustainable development. It is mean the close connection between intelligent innovation and eco-innovation. 
Eco-innovations decrease a total amount of emissions, health risks as well as, energy demands. The eco-innovations utilize circular economy, renewable resources of energy and new ecological materials (Lešková, 2009).

Therefore, The Slovak National Strategy of sustainable development mainly supports eco-innovations as approach of sustainable development. Eco-innovations are involved as main priorities not only in the Slovak Republic, but also in the EU, OSN and OECD. (Green Beings, 2015; Loučanová et al., 2015).

Eco-innovations can be accepted as a tool for companies to transform environmental constraints into opportunities of costs reduction or as a tool to get better reputation and advantage on the market. One of the most important interest of consumers is to promote the performance of environmental product innovations, in effort improve the realization of the innovations (Carillo-Hermossilla et al., 2010; Laperche, 2013; Loučanová et al, 2015).

\section{Methodology and empirical data}

The principal method of the research focused on perception of intelligent packaging in Slovakia as ecological innovations is methodology applied by the Kano model. The data have been analysed according to the methodology of Chen et al. (2010), Loučanová (2016), Ducák et al., (2006), Ullah \& Tamaki (2011) and Loučanová et al. (2015).

As Goodpasture (2003), Tomek \& Vávrová (2009) and Trommsdorff \& Steinhoff (2009). Above mention authors applied the Kano model for monitoring customers' views according to the requirements of the observed object which is elementary in a thorough understanding of the customer's.

To implement the Kano model, we took the following steps:

1. We identify the main requirements of the consumer: the perception of intelligent packaging, its availability, awareness, functionality, voice performance, attractiveness of packaging, advertising, freshness indicators and price.

2. We have prepared a Kano questionnaire according to Kano model rules according to pre-queried customer requirements, a positive and negative question is formulated to each single requirement. The respondents can respond within the scope of the Likert scale.

3. We set a sample of respondents - at a confidence level of $95 \%$, with a tolerance error of $+/-5 \%$ of the standard deviation of 0.5 . It was 384.16. It is mean 385 respondents. Research was attended by 552 respondents.

4. Evaluation of results and their interpretation - the Kano model approach classifies individual measured variables into requirements: mandatory or must by requirements, one-dimensional, attractive, irrelevant or questionable. Individual categories of ecological innovation requirements are characterized by Chen et al.

60 S sciendo Studia Universitatis "Vasile Goldis" Arad. Economics Series Vol 29 Issue 1/2019 ISSN: 1584-2339; (online) ISSN: 2285 - 3065

Web: publicatii.uvvg.ro/index.php/studiaeconomia. Pages 58 -67 
Loučanová, E., Parobek, J., Nosál'ová, M., Dopico, A. (2019)

The perception of respondents of intelligent packaging in Slovakia as ecological innovations

(2010), Loučanová (2016), Ducák et al., (2006), Ullah \& Tamaki (2011) and Loučanová et al. (2015). The categorized customer requirements are expressed as a share in the percent. Each percentage of the identified specific category represents a share of the identified requirements of the monitored attribute.

As the next step of analysis is a portfolio matrix that takes into account the environmental-focused enterprise strategies, the customer perception and satisfaction with smart innovations. The matrix is constructed based on the customer satisfaction coefficient with that innovation. It is calculated on the basis of the Kano model results according to the share of the individual customer requirements as stated by Krnáčová and Lesníková (2012) as follows:

$$
\text { Satisfaction coefficient }=\frac{A+O}{A+O+M+I}
$$

According to theory the Satisfaction coefficient represents the impact of customer satisfaction requirements ranging from 0 to 1 (the value closer to 1 , representing the greater satisfaction of customers with the requirement).

Subsequently, the values of the satisfaction coefficient of the individual examined parameters are assigned according to the given parameter to the groups characterizing the nature of the green customer and the ability to distinguish the product by this innovation. The arithmetic mean of the parameter values in each group represents the final value of the phenomenon under investigation within the nature of the green customer and the ability to distinguish the product by intelligent innovation. Then the values are applied to the portfolio matrix. Based on their location in the four quadrants, respondents adopt four environmental-oriented enterprise policy strategies: weak green, defensive green, extreme green and shadow green strategies (Bloom and Ginsberg, 2004).

\section{Empirical results}

The results summarize collected data to the Kano model and the portfolio matrix of the intelligent packaging on the environmental-oriented businesses and customer satisfaction. For the analyses, we apply the innovation decision-making methodology using a customer satisfaction rating with the assumed innovation, calculated on the basis of the Kano model results. The individual parameters examined within the Kano model were divided into two groups that characterize the nature of the green consumer and the ability to distinguish the product from competing products. Satisfaction coefficients and strategic decision-making groups are presented in table 2 for the nature of the green consumer and the ability to distinguish the product. 
Loučanová, E., Parobek, J., Nosál’ová, M., Dopico, A. (2019)

The perception of respondents of intelligent packaging in Slovakia as ecological innovations

Table 2 The Kano model values and environmental focus groups

\begin{tabular}{|l|c|c|c|}
\hline Monitored parameters & $\begin{array}{c}\text { Identified } \\
\text { requirements }\end{array}$ & Percentage & $\begin{array}{c}\text { Coefficients of } \\
\text { satisfaction }\end{array}$ \\
\hline Concept of intelligent packaging & attractive & 31.03 & 0.4578 \\
\hline Availability & indifferent & 52.41 & 0.0868 \\
\hline Awareness & reverse & 44.46 & 0.1033 \\
\hline Functionality & indifferent & 59.84 & 0.1532 \\
\hline The nature of the green consumer & \multicolumn{3}{|l}{0.2002} \\
\hline Voice performance & indifferent & 55.41 & 0.1010 \\
\hline Attractiveness of packaging & indifferent & 50.20 & 0.2464 \\
\hline Advertisement & indifferent & 49.54 & 0.1801 \\
\hline Freshness indicators & questionable & 35.59 & 0.4123 \\
\hline Price & indifferent & 45.11 & 0.0790 \\
\hline The ability to distinguish the product & \multicolumn{3}{|l}{0.2037} \\
\hline
\end{tabular}

Source: authors' computation

On the basis of the coefficients we can find that customers are satisfied with the concept of intelligent packaging, but the other monitored parameters reach quite low values. After applying the values to the portfolio matrix and based on their location in the four quadrants, the results shows the impact of intelligent innovations (focusing on intelligent packaging) on customer satisfaction with smart innovations, and their perception as weak green, see figure 1. 
Loučanová, E., Parobek, J., Nosál’ová, M., Dopico, A. (2019)

The perception of respondents of intelligent packaging in Slovakia as ecological innovations

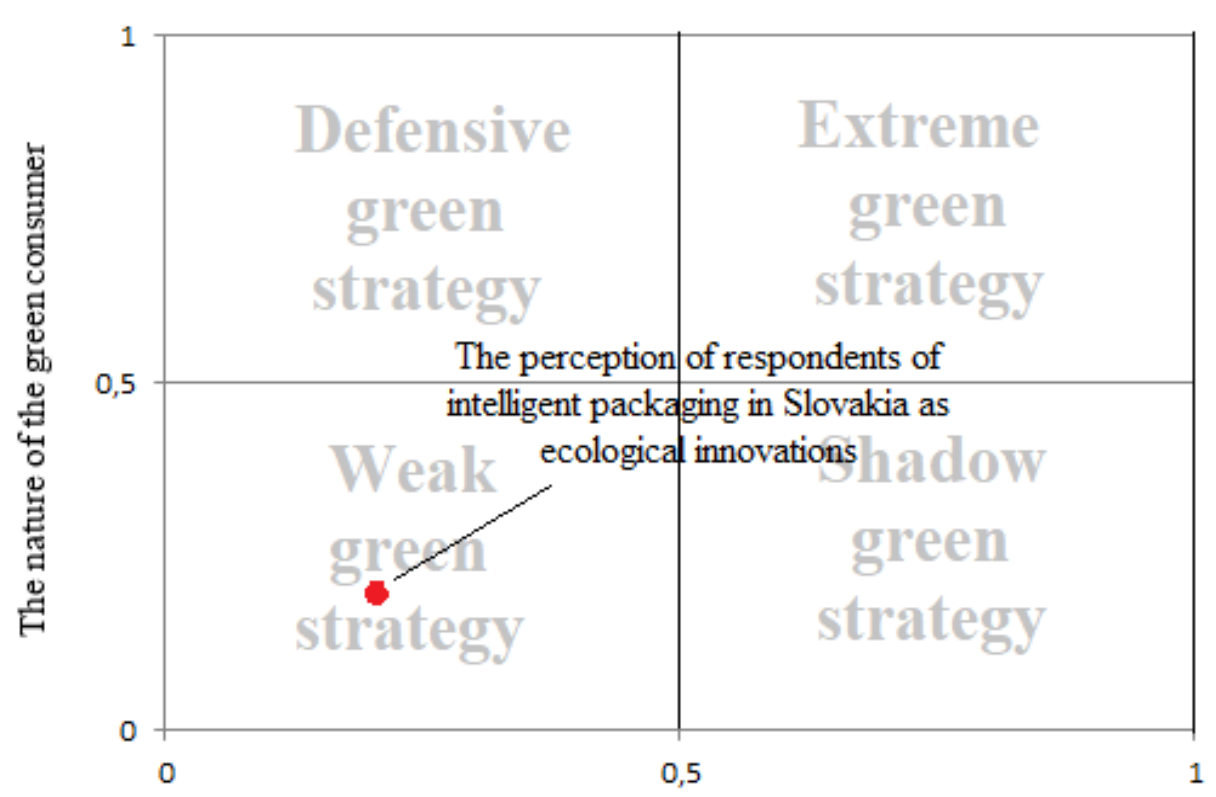

The ability to distinguish the product

Figure 1 Portfolio matrix of the intelligent innovation (packaging) on strategic environmental-oriented businesses and customer satisfaction

Source: authors' computation

With this strategy (see Figure 1), businesses are trying to be environmentally and socially responsible, but they are not aimed at promoting and marketing these environmental initiatives. These businesses are more interested in cost-cutting and efficiency-enhancing innovations through environmental initiatives and thus striving to achieve a competitive advantage resulting from low costs. The segment of green consumers is not looking for a segment that would bring them high profits. Such businesses are concerned that if their products were considered green, they would require a higher standard. These standard companies are not being able to implement. The companies are also worried that they will not be able to differentiate themselves from their competitors. Therefore, they prefer do not make their environmental initiatives public. This attitude can also be applied to customers. Within the given issue of intelligent innovation focusing on intelligent packaging, the results confirm them as well as companies, trying to be environmentally responsible. On the other hand, they haven't enough information 
and the main factor in their decision making is still price.

New innovations provide businesses with new competitive advantages. But not every company can use it for their benefit, mainly because of the acceptance by customers. In general, the conclusions of the analysis can be justified by the fact that younger age groups are focused on intelligent packaging performance. As Yam et al. (2005) describe that the packaging systems are capable of performing intelligent functions to facilitate decision making, increase security, improve quality, provide information and warn of possible problems. The customers also decide to a great extent on the attractiveness of the packaging, which represents the first customer contact with the product. As Helus (2015) and Kopaničová Klepochová (2016) stated it is a mental accelerator that facilitates cognitive processes in purchasing decisions. This is to automate the instructions for a certain situation or to intuitively simplify the decision when choosing from multiple options. The people decide according to the first impression of the innovation. That is the fact that companies need to accept and use to as an advantage.

As the results of this research show, notably in terms of awareness about smart innovations, there is great potential to reach out to customers for whom intelligent innovations are attractive. In this case the intelligent innovation products are an instrument of competitiveness at the market. The research presented on the basis of these analyzes provides both theoretical and practical information for innovators in the area of intelligent innovation issues specifically focused on active and intelligent packaging. The acquisition of theoretical knowledge can then lead to their real implementation in practice and help to increasing the performance of enterprises in their investment decisions in the context of innovation and environmental processes, as stated by several authors Ipate et al. (2015), Loučanová (2018) and other.

\section{Conclusions}

The intelligent innovations represent any autonomic change with positive impact to the customers. They increase the comfort of the customers and concurrently they represent more efficient, more economical, healthier and safer solution. This term is not so usual in Slovakia; however intelligent innovations are present on the market. For intelligent innovation assessment, we focused on intelligent packaging, the occurrence of which we have mostly noticed on the market. Research has clearly confirmed that customer awareness of intelligent innovations in Slovakia are still at a very low level and they are a weak in the green strategy. Customers do not recognize their individual parameters or identify them. Therefore, they do not positively evaluate their features. By increasing awareness of intelligent innovations, customers 'ability to evaluate their positives can be

64 S sciendo Studia Universitatis "Vasile Goldis" Arad. Economics Series Vol 29 Issue 1/2019 ISSN: 1584-2339; (online) ISSN: $2285-3065$

Web: publicatii.uvvg.ro/index.php/studiaeconomia. Pages $58-67$ 
Loučanová, E., Parobek, J., Nosál’ová, M., Dopico, A. (2019)

The perception of respondents of intelligent packaging in Slovakia as ecological innovations

further improved. In the future, they have the potential to represent a competitive advantage for products to meet customers' needs and to increase their satisfaction.

\section{Acknowledgements}

The authors thank the anonymous reviewers and editor for their valuable contribution.

\section{Funding}

This research was funded by Scientific Grant Agency of the Ministry of Education, Science, Research and Sport of the Slovak Republic and the Slovak Academy of Sciences, grant number 1/0674/19, "Proposal of a model for the eco-innovation integration into the innovation process of companies in Slovakia in order to increase their performance" and grant number 1/0666/19 "Determination of the development of a wood-based bioeconomy" and European Cooperation in the field of Scientific and Technical Research COST, COST Action FP1405 "Active and Intelligent Fibre-Based Packaging Innovation and Market Introduction (ACTINPAK)".

\section{Authors Contributions}

Erika Loučanová, Martina Nosálová, Ján Parobek and Ana Dopico elaborated chapters' literature review, methodology and empirical data, empirical results and conclusions.

\section{Disclosure Statement}

The authors declare no conflict of interest.

\section{References}

1. Bloom, P.N., Ginsberg, J.M., (2004), Choosing the right green marketing strategy. MIT Sloan management review, 46, (1), pp. 79-84.

2. Carrillo-Hermosilla J., del González P.R., Könnölä T. (2009). What is ecoinnovation? Eco-Innovation. Palgrave Macmillan, London

3. Chen, L.S. et al., (2010), C Kano Model: a Novel Approach for Discovering Attractive Quality Elements, Total Quality Management, 21 (11), pp. 1189-1214.

4. Ducár, S., Naščáková, J., Malák, M., (2006), Návrh systému merania spokojnosti zákazníkov Kano modelom, Transfer inovácií, 9, pp. 137-139.

5. Dzurová, M., (1997), Obal a balenie ako súčast' logistiky, Bratislava: Eurounion.

6. Goodpasture, J., (2003), Quantitative Methods in Project Management, USA: J. Ross Publishing. 
7. Green Beings, (2015), Eco Innovations - how eco ideas become a reality, (n.d.). [online] [cit. 10.03.2015] Available from: http://www.greenbeings.com.au/tips/eco-innovations.aspx

8. Helus, Z., (2015), Sociálni psychologie pro pedagogy, Praha: Grada.

9. Ipate, N., David, K.G., Ipate, I., Bogdan, A., (2015). The bioeconomy model in future sustainable development, Studia Universitatis "Vasile Goldiş" Arad. Economics Series, 25, 2/2015.

10. Kačenák, I., (1996), Balenie tovaru, Bratislava: Ekonóm.

11. Kopaničová, J., Klepochová, D., (2016), Consumers in New Millennium: Attitudes towards Adoption of New Technologies in Purchasing Process, Studia commercialia Bratislavensia 9, (33), pp. 65-74.

12. Krnáčová, P., Lesníková, P., (2012), Kano model spokojnosti zákazníka v neziskovom sektore, Bratislava: Ekonóm.

13. Laperche, B., Picard, F., (2013), Environmental constraints, ProductService Systems development and impacts on innovation management: learning from manufacturing firms in the French context, Journal of Cleaner Production, 53, pp. 118-128.

14. Lešková, A., (2009), Politika eko-inovácií a jej prejavy v automobilovom priemysle, TU, Košice. pp. 40. [online] [cit. 20.5.2014], Available from: http://www.sjf.tuke.sk/transferinovacii/pages/archiv/transfer/132009/pdf/037-040.pdf

15. Loučanová, E., Kalamárová, M., Parobek, J., (2017), The innovative approaches to packaging - comparison analysis of intelligent and active packaging perceptions in Slovakia, Studia Universitatis „Vasile Goldiş” Arad, Economics Series, 27 (2), pp. 33-44.

16. Loučanová, E., Nosálová, M., Parobek, J., Dopico, A., (2018), The Kano model use to evaluate the perception of intelligent and active packaging of Slovak customers, Studia Universitatis „Vasile Goldiş” Arad. Economics Series, 28 (1), pp. 35-45.

17. Loučanová, E., Parobek, J., Kalamárová, M., Paluš, H., Lenoch, J., (2015), Eco-innovation performance of Slovakia, Procedia - economics and finance 26, pp. 920-924.

18. Loučanová, E., Parobek, J., Kalamárová, M., (2015), Retro-innovation and corporate social responsibility, Studia Universitatis „Vasile Goldiş” Arad. Economics Series, 25 (4), pp. 1-10.

19. Loučanová, E., Parobek, J., Kalamárová, M., (2016), The perception of respondents of packaging innovations in Slovakia, Studia Universitatis „Vasile Goldiş” Arad. Economics Series, 26 (3), pp. 33-43. 
20. Pajtinková, Bartáková, G., Gubíniová, K., (2012), Udržatel’ný marketingový manažment, Bratislava: 1AM press.

21. Paluš, H., (2004), Trvalo udržatel’ný rozvoj a certifikácia lesov, Nová ekonomika, 3(2), pp. 63-68

22. Regattieri, A., Santarelli, G., Gamberi, M., Mora, C., (2014), A new paradigm for packaging design in web-based commerce, International Journal of Engineering Business Management, 6(1), pp. 1-11.

23. Richterová, K., et al., (1999), Kapitoly z marketingového výskumu, Bratislava: Ekonóm.

24. Straka, M., (2013), Logistika distribúcie, Ako efektívne dostat' výrobok na trh. EPOS, Bratislava.

25. Šupín, M., (2009), Megatrendy vo vývoji svetového hospodárstva a možnosti Slovenskej republiky zmäkčit' dôsledky hospodárskej krízy, Marketing a obchod 2009, pp. 5-8.

26. Tomek, G., Vávrová, V., (2009), Jak zvýšit konkurenční schopnost firmy, Praha: C.H. Beck.

27. Trommsdorff, V., Steinhoff, F., (2009), Marketing inovací, Praha: C.H. Beck.

28. Ullah, S.A.M.M., Tamaki J., (2011), Analysis of Kano-model-based customer needs for product development, Systems Engineering, 14, pp. 154-172.

29. Yam, K.L., Takhistov, P.T., Miltz, J., (2005), Intelligent Packaging: Concepts and Applications, Journal of Food Science, 70 (1).

30. Zeman, S., (2005), Balenie a obalová technika, Nitra: Slovenská pol'nohospodárska univerzita. 